\title{
KESULITAN YANG DIHADAPI GURU KIMIA DI SMAN 03 BOMBANA DALAM MENERAPKAN KURIKULUM 2013
}

\author{
Suciatni Elsa Husnawawi ${ }^{1}$, Dahlan², Maysara³ \\ 1,2,3]urusan Pendidikan Kimia FKIP Universitas Halu Oleo, Kendari \\ Corresponding author: maysara.fkip@uho.ac.id
}

\begin{abstract}
Research on the difficulties faced by Chemistry Teachers at SMAN 03 Bombana in Implementing the 2013 Curriculum has been carried out. This study aims to determine the difficulties faced by teachers in designing Learning Implementation Plans (RPP) in the 2013 curriculum, to determine the difficulties of teachers in implementing learning in the 2013 curriculum and to find out difficulties faced by teachers in carrying out learning assessments in the 2013 curriculum. This research was conducted at SMAN 03 Bombana class X, XI and XII in the even semester of the 2019/2020 academic year. This type of research is qualitative research. The focus of this research is the difficulties of the chemistry teacher covering learning planning, implementation and assessment of learning in the 2013 curriculum. The data in this study were obtained by interview and documentation methods. The data validity test includes extension of observations and using reference materials. The data analysis used consisted of data reduction, data presentation and data verification. The results showed that the chemistry teachers at SMAN 03 Bombana still experienced difficulties in preparing lesson plans including determining the learning model, allocating learning time, developing indicators, planning learning steps and assessments. In the implementation of teaching learning, teachers also still experience difficulties, especially in the application of learning models and scientific approaches. Meanwhile, in teacher assessment, it is still difficult for teachers to apply learning assessments according to the demands of the 2013 curriculum. data presentation and data verification.
\end{abstract}

Keywords: Teacher difficulties, lesson planning, learning implementation, learning assessment, 2013

\section{PENDAHULUAN}

Salah satu bagian terpenting yang mendukung keterlaksanaan proses pendidikan di Indonesia adalah kurikulum. Kurikulum merupakan ciri utama atau syarat mutlak bagi pendidikan formal. Kurikulum adalah suatu rencana yang memberi pedoman dalam proses kegiatan belajar mengajar. Di dalam sebuah kurikulum terdapat beberapa komponen-komponen yaitu tujuan, bahan ajar, model pembelajaran, metode dan media pembelajaran serta penilaian (Jafar dkk, 2018). 
Dalam sistem pendidikan di Indonesia, kurikulum telah mengalami beberapa kali perubahan sejak diberlakukannya kurikulum pertama yaitu kurikulum 1947. Perubahan terakhir terjadi pada Kurikulum Tingkat Satuan Pendidikan (KTSP) menjadi kurikulum $2013 . \quad$ Tujuan pengembangan kurikulum 2013 adalah untuk mendorong peserta didik atau siswa untul lebih aktif lagi selama pembelajaran terutama bertanya, bernalar, dan mengkomunikasikan data data yang diperoleh atau diketahui setelah siswa menerima materi pembelajaran (Anwar, 2014). Tujuan lain dari perubahan kurikulum adalah untuk mengikuti perkembangan zaman yang semakin modern, agar siswa dan generasi muda Indonesia tidak ketinggalan dan mampu bersaing tidak hanya secara nasional tetapi juga mampu bersaing dikancah Internasional.

Kurikulum 2013 merupakan inovasi dan penyempurnaan dari kurikulum sebelumnya dengan tujuan untuk meningkatkan kualitas proses pendidikan melalui pengembangan Kurikulum Berbasis Kompetensi pada tahun 2004. Fokus pengembangan kurikulum dilakukan pada pembentukan kompetensi dan karakter peserta didik, berupa paduan pengetahuan, keterampilan, dan sikap yang dapat didemonstrasikan peserta didik sebagai wujud pemahaman terhadap konsep yang dipelajari secara konseptual. Pengembangan kurikulum 2013 diharapkan mampu meningkatkan kualitas lulusan, menghasilkan insan Indonesia yang produktif, kreatif, inovatif, afektif melalui penguatan sikap, keterampilan, dan pengetahuan yang terintegrasi (Kusumastuti dkk, 2016). Menurut Sofyan perubahan kurikulum menuntut perubahan paradigma pembelajaran dari teaching ke learning, dari teaching community ke learning community. Dengan demikian, guru dituntut untuk kreatif dan inovatif dalam mendesain pembelajaran agar peserta didik termotivasi dan merasa senang selama pembelajaran berlangsung. Oleh Karena itu, harus ada upaya-upaya dari guru tentang bagaimana mengembangkan pembelajaran agar pembelajaran menjadi menarik, menyenangkan, memotivasi siswa untuk belajar mandiri. Proses belajar mengajar dengan kurikulum 2013 menuntut peserta didik untuk belajar secara mandiri dengan guru yang berperan sebagai fasilitator untuk mengembangkan kemampuan siswa dalam berpikir kritis, aktif dalam kegiatan pembelajaran, kreatif, serta mampu mengkomunikasikan hasil yang diperoleh melalui pembelajaran.

Kurikulum 2013 memiliki beberapa kelebihan/keunggulan diantaranya; 1) Siswa lebih dituntut untuk aktif, kreatif dan inovatif dalam setiap pemecahan masalah yang mereka hadapi di sekolah, 2) adanya penilaian dari semua aspek. Penentuan nilai bagi siswa bukan hanya didapat dari nilai ujian saja tetapi juga didapat dari nilai

JPKim FKIP UHO, Vol.6, No.2, Agustus 2021| Hal. 75 
kesopanan, religi, praktek, sikap dan lain-lain, 3) munculnya pendidikan karakter dan pendidikan budi pekerti yang telah diintegrasikan ke dalam semua program studi (Trisnawati dkk, 2016). Akan tetapi kelebihan yang dimiliki kurikulum 2013 tidak dapat menutupi fakta dilapangan bahwa masih banyak permasalahanpermasalahan dalam penerapan kurikulum 2013, terutama permasalahan yang dialami guru. Permasalahan yang paling banyak terjadi adalah kesulitan guru dalam membuat perencanaan pembelajaran serta kesulitan dalam pelaksanaan pembelajaran yang sesuai dengan langkah langkah pembelajaran sesuai dengan kurikulum 2013.

Pada kurikulum 2013, pendekatan yang digunakan dalam pembelajaran menggunakan adalah pendekatan saintifik. Pendekatan saintifik adalah pendekatan dalam proses pembelajaran yang dirancang sedemikian rupa agar peserta didik secara aktif mengonstruksi konsep, hukum atau prinsip melalui tahapan-tahapan dalam mengidentifikasi atau menemukan masalah), merumuskan masalah, mengajukan atau merumuskan hipotesis, mengumpulkan data dengan berbagai teknik, serta menganalisis data-data yang diperoleh. Dari data data tersebut siswa dapat menarik kesimpulan dan mengkomukasikan konsep, hukum atau prinsip yang ditemukan. Penerapan pendekatan saintifik dalam pembelajaran melibatkan keterampilan proses seperti mengamati, mengklarifikasi, mengukur, meramalkan, menjelaskan, dan menyimpulkan (Budiyanto dkk, 2016).

Faktor utama yang menjadi perhatian pemerintah dalam penerapan kurikulum 2013 adalah guru. Menurut Wangid dkk (2014) guru sebagai motor utama penentu keberhasilan penerapan kurikulum 2013. Kesiapan dan pemahaman guru terhadap ruh kurikulum 2013 harus dimiliki oleh semua guru. Pemahaman inilah yang akan menjadikan guru bisa melakukan tindakan yang sesuai dengan maksud dan tujuan yang ada dalam kurikulum 2013. Dengan demikian kesiapan dan pemahaman guru terhadap kurikulum 2013 ini menjadi hal yang sangat menentukan dalam keberhasilan dan pencapaian tujuan dari kurikulum 2013.

Perencanaan pembelajaran, pelaksanaan pembelajaran, dan penilaian pembelajaran merupakan bagian terpenting dari keterlaksanaan kurikulum 2013 yang harus dijalankan oleh guru sebagai pelaksana kurikulum. Perencanaan pembelajaran merupakan sesuatu hal yang penting bagi guru dalam menjalankan tugasnya. Perencanaan pembelajaran adalah proyeksi tentang sesuatu yang akan dilakukan oleh guru dalam proses belajar mengajar. Pembelajaran akan optimal jika guru terlebih dahulu menyiapkan perencanaan (Nadzir, 2013). Tujuannya agar guru dapat melakukan kegiatan dan aktivitas pembelajaran di kelas secara terstruktur. Proses 
pembelajaran merupakan suatu proses yang mengandung serangkaian pelaksanaan oleh guru dan siswa atas dasar hubungan timbal balik yang berlangsung dalam situasi edukatif untuk mencapai tujuan tertentu. Interaksi atau hubungan timbal balik antara guru dan siswa ini merupakan syarat utama bagi berlangsungnya proses pembelajaran (Fakhrurrazi, 2018). Kegiatan pembelajaran memiliki tujuan yaitu tercapainya tujuan pembelajaran meliputi perubahan perilaku dari peserta didik (pengetahuan, sikap dan keterampilan). Maka menerapkan langkah-langkah kegiatan pembelajaran yang telah disusun sangat diperlukan, untuk mengotrol proses pembelajaran dalam kelas dengan baik dan memperoleh hasil pembelajaran yang sesuai dengan tujuan pembelajaran. Tahapan akhir dari seluruh kegiatan pembelajaran adalah penilaian. Penilaian merupakan serangkaian kegiatan untuk memperoleh, menganalisis, dan menafsirkan data tentang proses dan hasil belajar siswa yang dilakukan secara sistematis dan berkesinambungan, sehingga menjadi informasi yang bermakna dalam pengambilan keputusan (Suyatmini, 2017). Oleh sebab itu pengetahuan seorang guru tentang proses penilaian dalam Kurikulum 2013 sangat penting, guru sebagai pelaksana kurikulum perlu mengetahui bagaimana melakukan penilaian sesuai kurikulum 2013. Ekawati penelitiannya $\begin{array}{lcr}\text { permasalahan } & \text { guru } & \text { dalam } \\ \text { penerapan } & \text { kurikulum } & 2013 \\ \text { melaporkan } & \text { bahwa } & \text { dalam } \\ \text { implementasi } & \text { kurikulum } & 2013\end{array}$ menghadapi beberapa masalah pada empat guru yang menjadi sumber data dalam penelitian, permasalahannya meliputi persiapan pembelajaran, penerapan langkah-langkah kegiatan pembelajaran (pendekatan ilmiah), menyiapkan media, dan membuat penilaian (evaluasi). Guru-guru responden menyatakan bahwa mempersiapkan rencana pelajaran sebelum proses belajar mengajar itu penting tetapi sulit dilakukan karena waktu yang terbatas untuk melakukan persiapan. Selain itu, masalah terjadi ketika guru menerapkan langkah-langkah pendekatan ilmiah. Media sebagai alat untuk mendukung materi disediakan dalam jumlah terbatas dan untuk mengevaluasi pemahaman siswa, guru juga menemukan masalah. Tampaknya sulit mengukur sesuatu yang abstrak seperti aspek spiritual dan sikap. Selain itu, mereka juga mendapat kesulitan dalam memberikan skor ketika mengamati sikap dan keterampilan berbicara siswa. Hal ini menggambarkan bahwa guru masih memiliki banyak kesulitan dalam penerapan proses pembelajaran menggunakan kurikulum 2013 terutama pada tahap persiapan atau perencanaan pembelajaran, pelaksanaan pembelajaran serta evaluasi.

Hasil penelitian dari beberapa jurnal menunjukkan masih terdapat berbagai kesulitan dalam penenerapan kurikulum 2013 
terutama dalam kegiatan perencanaa, pelaksanaan dan penilaian. Berdasarkan hasil wawancara yang telah dilakukan dengan guru kimia di SMAN 03 Bombana mengatakan bahwa dalam pembelajaran menggunakan kurikulum 2013 guru masih mengalami kesulitan. Berdasarkan latar belakang yang dikemukakan, maka peneliti tertarik untuk melakukan penelitian tentang "Kesulitan yang dihadapi Guru Kimia di SMAN 03 Bombana dalam Menerapkan Kurikulum 2013".

\section{METODE PENELITIAN}

Jenis

digunakan yang adalah penelitian kualitatif. Tekhnik pengumpulan data dilakukan secara triangulasi (gabungan), analisis data bersifat induktif, dan hasil penelitian kualitatif lebih menekankan makna dari pada generalisasi.

\section{Fokus Penelitian}

Fokus Penelitian dalam penelitian ini adalah kesulitan guru kimia terhadap penerapan kurikulum 2013 di SMAN 03 Bombana meliputi kegiatan perencanaan pembelajaran, pelaksanaan pembelajaran serta penilaian.

\section{Teknik Pengumpulan Data}

a. Metode Wawancara

Pengumpulan data dalam penelitian ini menggunakan metode wawancara semi terstruktur. Tujuan dari wawancara jenis ini adalah untuk menemukan permasalahan secara terbuka, dimana pihak yang diajak wawancara diminta pendapat, dan ide-idenya. Dalam melakukan wawancara, peneliti mendengarkan secara teliti dan mencatat apa yang dikemukakan oleh informan, hal ini mengscu pada (Sugiyono,2018). Pedoman wawancara yang digunakan merujuk pada Ekawati (2017).

\section{b. Metode Dokumentasi}

Dokumentasi, digunakan dalam penelitian ini karena setiap kegiatan dan tindakan yang akan dilakukan memerlukan bukti yang akurat dan bukti nyata yang dapat dillihat oleh orang lain. Dengan dokumentasi ini dapat mengumpulkan informasi dengan bukti nyata yang dapat dilihat langsung bentuknya (Diharja, 2017). Dalam penelitian ini dokumen yang di kumpulkan adalah Rencana Pelaksanaan Pembelajaran (RPP) yang dibuat oleh guru dan berbagai format penilaian pembelajaran yang digunakan guru serta kegiatan wawancara dengan guru yang di dokumentasikan dalam gambar. Pedoman analisis RPP dan penilaian pembelajaran merujuk pada pemerintah provinsi Sulawesi Tenggara, Dinas Pendidikan dan Kebudayaan.

\section{Uji Keabsahan Data}

\section{a. Perpanjangan Pengamatan Melakukan perpanjangan} pengamatan bertujuan menguji kredibilitas data yang diperoleh, dengan perpanjangan pengamatan berarti peneliti kembali kelapangan untuk melakukan pengamatan serta wawancara kepada sumber data (Sugiyono, 2018).

b. Menggunakan Bahan Referensi 
Bahan referensi yang dimaksud adalah adanya pendukung untuk membuktikan data yang diperoleh selama penelitian. Bahan referensi meliputi alat perekam yang

\section{HASIL DAN PEMBAHASAN}

\section{Perencanaan Pembelajaran}

Perencanaan pembelajaran yang diteliti adalah perangkat pembelajaran yang dibuat oleh guru mata pelajaran kimia yaitu Rencana Pelaksanaan Pembelajaran (RPP). digunakan saat wawancara dan kamera yang digunakan untuk mendokumentasikan kegiatan penelitian (Sugiyono, 2018).

Data mengenai perencanaan pembelajaran yang digunakan guru diperoleh dari analisis dokumen. Hasil analisis dokumen pada Rencana Pelaksanaan Pembelajaran (RPP) guru disajikan dalam tabel berikut:

Tabel 1. Hasil observasi Rencana Pelaksanaan Pembelajaran (RPP)

\begin{tabular}{|c|c|c|c|c|c|}
\hline \multirow{3}{*}{ No } & \multirow{3}{*}{$\begin{array}{c}\text { Aspek yang } \\
\text { Diamati }\end{array}$} & \multicolumn{4}{|c|}{ Skor } \\
\hline & & \multicolumn{2}{|c|}{$Y_{1}$} & \multicolumn{2}{|c|}{$\mathbf{Y}_{2}$} \\
\hline & & $Y_{1.1}$ & $\mathbf{Y}_{1.2}$ & $Y_{2.1}$ & $Y_{2.2}$ \\
\hline 1 & $\begin{array}{ll}\text { Identitas } & \text { mata } \\
\text { pelajaran }\end{array}$ & 14 & 14 & 14 & 14 \\
\hline 2 & $\begin{array}{l}\text { Indikator pencapaian } \\
\text { kompetensi }\end{array}$ & 6 & 10 & 8 & 8 \\
\hline 3 & $\begin{array}{l}\text { Tujuan } \\
\text { pembelajaran }\end{array}$ & 4 & 6 & 4 & 4 \\
\hline 4 & Materi ajar & 3 & 4 & 2 & 2 \\
\hline 5 & $\begin{array}{l}\text { Metode } \\
\text { pembelajaran }\end{array}$ & 4 & 4 & 3 & 3 \\
\hline 6 & $\begin{array}{l}\text { Alat dan media } \\
\text { pembelajaran }\end{array}$ & 4 & 2 & 3 & 4 \\
\hline 7 & $\begin{array}{l}\text { Kegiatan } \\
\text { pembelajaran }\end{array}$ & 18 & 19 & 18 & 18 \\
\hline 8 & $\begin{array}{l}\text { Penilaian } \\
\text { pembelajaran }\end{array}$ & 3 & 3 & 0 & 0 \\
\hline & Jumlah Skor & 56 & 62 & 52 & 53 \\
\hline & $\begin{array}{c}\text { Presentase } \\
\text { Kriteria }\end{array}$ & $\begin{array}{l}75,6 \% \\
\text { Cukup }\end{array}$ & $\frac{83,7 \%}{\text { Baik }}$ & $\begin{array}{l}70,2 \% \\
\text { Cukup }\end{array}$ & $\begin{array}{l}71,6 \% \\
\text { Cukup }\end{array}$ \\
\hline
\end{tabular}

Dari data Tabel 1 menunjukkan bahwa RPP yang digunakan guru kimia di SMAN 03 Bombana cukup baik. Hal ini dapat dilihat dari persentase masing-masing RPP yang dimiliki oleh guru serta kriteria yang diperoleh. Ketidaktercapaian persentase maksimum yaitu $100 \%$ dalam RPP yang disusun kedua guru dikarenakan adanya beberapa komponen RPP yang tidak dimasukkan oleh guru kedalam RPP yang dirancang serta adanya komponen yang tidak mencapai batas maksimal penilaian. Secara umum 
kesesuaian RPP yang dibuat oleh guru dengan sistematika yang telah di tentukan dalam kurikulum 2013 telah sesuai. Hal ini dikarenakan guru telah mengikuti pelatihan tentang kurikulum 2013.

Bagi seorang guru menyiapkan Rencana Pelaksanaan Pembelajaran merupakan hal yang sangat penting. Perencanaan pembelajaran atau RPP memainkan peran penting dalam memandu guru melaksanakan tugas sebagai pendidik dalam melayani kebutuhan belajar siswa-siswanya (Harahap dan Nazlia, 2019). Berdasarkan hasil wawancara terkait mempersiapkan Rencana Pelaksanaan Pembelajaran, kedua guru kimia mengatakan bahwa mereka selalu menyiapkan RPP sebelum kegiatan pembelajaran berlangsung. Hal ini menandakan bahwa kedua guru tersebut memahami apa itu RPP dan menyadari pentingnya menyiapkan RPP sebelum melakukan kegiatan pembelajaran.

Tidak banyak guru yang mampu merancang RPP sesuai tuntutan kurikulum 2013. Seperti halnya pada guru kimia di SMAN 03 Bombana, dari hasil wawancara guru terkait kendala dalam mempersiapakan RPP, kedua guru memiliki jawaban yang berbeda. Guru pertama mengalami kesulitan dalam mempersiapkan RPP terutama pada penilaian pembelajaran dan penentuan model dan metode pembelajaran. Karena dalam penentuan model dan metode guru harus menyesuaikan dengan karakteristik yang dimiliki siswa.
Kesulitan guru tersebut juga dapat dilihat dari persentase RPP yang diperoleh yaitu $75,6 \%$ dan $83,7 \%$ yang belum masuk dalam kriteria sangat baik meskipun terdapat satu RPP yang memperoleh kriteria baik. Masih terdapat sekitar 24,4\% dan $16,3 \%$ komponen RPP yang belum terpenuhi yang tidak mencapai skor maksimal penilaian dan tidak dimasukkan oleh guru kedalam RPP.

Guru kedua menyatakan tidak mengalami kesulitan dalam mempersiapkan RPP. Akan tetapi dari hasil analisis RPP yang dimiliki oleh guru kedua, masih terdapat kekurangan dalam RPP guru tersebut. Kekurangan tersebut dapat dilihat dari persentase RPP yang diperoleh yaitu $70,2 \%$ dan $71,6 \%$ yang masih jauh dari kriteria sangat baik karena masih terdapat $29,8 \%$ dan $28,4 \%$ komponen yang tidak terpenuhi dan belum mencapai skor maksimal terutama pada materi ajar yang hanya mencapai skor 2 dari skor maksimal 8 dan juga penilaian pembelajaran yang memperoleh skor 0. Berdasarkan perolehan persentase RPP dapat dilihat bahwa kedua guru tersebut masih mengalami kesulitan dalam merancang RPP sesuai tuntutan kurikulum 2013.

Selain itu, kedua guru juga mengalami kesulitan dalam mengalokasikan waktu pembelajaran. Menurut kedua guru alokasi waktu yang tersedia 
untuk kegiatan pembelajaran umumnya tidak mencukupi. Hal ini dikarenakan tingkat kemampuan siswa yang rendah dalam memahami materi sehingga guru membutuhkan waktu lebih dalam pembelajaran serta materi pembelajaran juga mempengaruhi alokasi waktu yang dibutuhkan guru, semakin sulit materi yang akan diajarkan semakin banyak waktu yang di butuhkan oleh guru untuk menyelesaikan materi tersebut.

Kesulitan yang dihadapi guru terhadap beberapa komponen RPP diantaranya mengalokasikan waktu pembelajaran. Menurut kedua guru alokasi waktu yang tersedia untuk kegiatan pembelajaran umumnya tidak mencukupi. Hal ini dikarenakan tingkat kemampuan siswa yang rendah dalam memahami materi sehingga guru membutuhkan waktu lebih dalam pembelajaran serta materi pembelajaran juga mempengaruhi alokasi waktu yang dibutuhkan guru, semakin sulit materi yang akan diajarkan semakin banyak waktu yang di butuhkan oleh guru untuk menyelesaikan materi tersebut.

Komponen selanjutnya yaitu indikator pencapaian kompetensi (IPK) yang merupakan salah satu komponen yang sangat penting dalam RPP. Dari hasil wawancara guru terkait IPK, kedua guru mengatakan mereka tidak mengalami kesulitan dan mampu mengembangkan indikator pembelajaran dari kompetensi dasar yang sudah di tentukan. Hal ini tidak sejalan dengan hasil analisis RPP terkait indikator pembelajaran. IPK yang disusun oleh guru pertama pada RPP materi pertama hanya memperoleh skor 6 . Hal ini dikarenakan pada RPP guru tersebut ditemukan bahwa guru tidak mengembangkan satu indikator pencapaian kompetensi yaitu pada indikator aspek keterampilan dan adanya beberapa komponen dalam indikator yang dirancang oleh guru tidak sesuai dengan beberapa aspek yang diamati oleh peneliti diantaranya guru tidak menuliskan indikator jembatan dan indikator target/kunci yang sesuai dengan KD. Kemudian guru pertama juga tidak mengembangkan indikator keterampilan pada materi tersebut. Sedangkan pada guru kedua memperoleh skor IPK yang sama pada kedua RPP dirancang yaitu 8 dari skor maksimal. Alasannya karena salah satu IPK yang dirumuskan guru tersebut tidak menggunakan kata kerja yang dapat diukur dan diamati.

\section{Pelaksanaan Pembelajaran}

Observasi pelaksanaan pembelajaran dengan kurikulum 2013 terhadap dua guru kimia di SMAN 03 Bombana tidak dapat terlaksana secara langsung dikarenakan situasi dan kondisi saat penelitian yang kurang mendukung akibat Covid-19. Oleh karena itu peneliti membahas pelaksanaan pembelajaran kurikulum 2013 sesuai dengan hasil wawancara langsung dengan

JPKim FKIP UHO, Vol.6, No.2, Agustus 2021| Hal. 81 
kedua guru kimia. Pelaksanaan pembelajaran menggunakan kurikulum 2013 di SMAN 03 Bombana mengalami kesulitan pada penggunaan pendekatan pembelajaran dan penerapan model pembelajaran di dalam kelas.

Kegiatan pembelajaran dalam kurikulum 2013 terdiri atas tiga yaitu kegiatan pendahuluan, kegiatan inti serta penutup. Berdasarkan hasil wawancara dengan kedua guru kimia mengatakan bahwa guru selalu melakukan kegiatan pendahuluan, karena kegiatan ini merupakan salah satu bagian yang sangat penting untuk membuat siswa fokus dalam pembelajaran. Kegiatan yang sering dilakukan guru kimia di SMAN 03 Bombana selain menyiapkan peserta didik secara fisik dan psikis, guru juga melakukan kegiatan apersepsi dan juga memotivasi siswa. Menurut kedua guru kegiatan apersepsi sangat penting untuk mengaitkan materi yang sebelumnya di ajarkan dengan materi yang akan diajarkan.

Sedangkan pada kegiatan inti pembelajaran guru mendapatkan kesulitan pada penerapan pendekatan saintifik. Menurut guru permasalahan terdapat pada siswa, meskipun media pembelajaran telah lengkap disediakan oleh sekolah, karena kemampuan akademik yang kurang baik sehingga guru kesulitan untuk menerapkan pendekatan ini. Berdasarkan hasil wawancara terkait penerapan pendekatan saintifik guru pertama menjawab bahwa dalam pembelajaran guru tersebut selalu berusaha menerapan pendekatan ini meskipun kadang kurang maksimal.
Hal ini membuktikan bahwa guru tersebut mengalami kesulitan dalam menerapkan pendekatan saintifik. Sedangkan guru kedua mengatakan bahwa guru tersebut tidak menerapkan pendekatan saintifik.

Selain itu permasalahan lainnya terdapat pada penerapan model pembelajaran yang telah ditentukan oleh guru dalam RPP yang dibuat. Kedua guru mengatakan bahwa mereka tidak menggukan model pembelajaran ketika kegiatan belajar mengajar berlangsung. Alasannya kedua guru merasa kesulitan untuk menerapkan model pembelajaran kepada siswa, mengingat kemampuan akademik siswa yang kurang baik sehingga siswa tidak dapat mandiri dalam menyelesaikan permasalahan dalam pembelajaran. Oleh karena itu proses pembelajaran yang dilakukan harus berpusat kepada guru. Akan tetapi untuk penggunaan metode yang variatif kedua guru tersebut menggunakan berbagai metode dalam pembelajaran dengan alasan agar proses pembelajaran dapat berjalan dalam suasana yang menyenangkan dan tidak membosankan.

Respon siswa dalam proses pembelajaran menggunakan kurikulum 2013 menurut kedua guru kurang baik. Hal ini dikarenakan kemampuan siswa menganalisa suatu materi yang rendah sehingga akan sangat sulit jika pembelajaran sepenuhnya 
dilakukan menggunakan kurikulum 2013. Sedangkan untuk keaktifan siswa selama pembelajaran dengan kurikulum 2013 guru merasa siswa kurang aktif, sehingga pembelajaran didalam kelas harus berpusat kepada guru.

\begin{tabular}{ccc}
\multicolumn{1}{c}{ Kegiatan } & penutup & yang \\
merupakan & kegiatan & akhir \\
pembelajaran. & Kedua & guru
\end{tabular}
menyatakan bahwa mereka selalu melakukan kegiatan ini. Kegiatan yang dilakukan diantaranya menyimpulkan materi pembelajaran dan menyampaikan materi yang akan diajarkan dipertemuan selanjutnya.

\section{Penilaian Pembelajaran}

Penilaian merupakan salah satu bagian dari proses belajar mengajar. Penilaian bertujuan mengukur sejauh mana tujuan pembelajaran telah dicapai (Wuryani dan Irham, 2014).

Tabel 2. Penilaian Pembelajaran Kurikulum 2013

\begin{tabular}{|c|c|c|c|c|c|}
\hline \multirow[b]{2}{*}{ No } & \multirow[b]{2}{*}{ ASPEK PENILAIAN } & \multicolumn{3}{|c|}{$\mathbf{Y}_{1}$} & \multirow{2}{*}{$\frac{Y_{2}}{Y_{2,2}}$} \\
\hline & & $Y_{1.1}$ & $Y_{1.2}$ & $Y_{2.1}$ & \\
\hline \multirow[t]{4}{*}{1.} & Penilaian pengetahuan & & & & \\
\hline & - Tes Tertulis & $\checkmark$ & $\checkmark$ & - & - \\
\hline & - Tes Lisan & - & - & - & - \\
\hline & - Penugasan & - & - & - & - \\
\hline \multirow[t]{5}{*}{2.} & Penilaian Keterampilan & & & & \\
\hline & -Unjuk Keria/praktik/kinerja & $\checkmark$ & $\checkmark$ & - & - \\
\hline & - Projek & - & - & - & - \\
\hline & - Produk & - & - & - & - \\
\hline & - Portopolio & - & - & - & \\
\hline \multirow[t]{4}{*}{3.} & Penilaian Sikap & & & & \\
\hline & - Observasi & $\checkmark$ & $\checkmark$ & - & - \\
\hline & - Penilaian Diri & - & - & - & - \\
\hline & - Penilaian Teman Sebava & 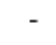 & - & - & - \\
\hline
\end{tabular}

Dari data pada Tabel 2 tersebut, menunjukkan bahwa guru di SMAN 03 Bombana belum menyiapkan instrumen penilaian dengan begitu baik. Hal tersebut dapat dilihat dari instrumen penilaian dalam RPP yang di rancang oleh guru. Guru pertama telah merancang penilaian pembelajaran yang akan digunakan dengan cukup baik meskipun masih terdapat beberapa jenis penilaian yang tidak digunakan Sedangkan guru kedua tidak merancang penilaian pembelajaran sama sekali.

Kesesuaian antara instrumen penilaian yang dirancang oleh guru pertama dengan tujuan pembelajaran yang akan dicapai telah cukup sesuai seperti pada instrumen penilaian tes tertulis, guru pertama telah membuat soal tes dengan sangat baik. Hal ini dapat dilihat dari kesesuaian antara soal tes tertulis dengan tujuan pembelajaran yang akan dicapai. Sedangkan untuk instrumen penilaian keterampilan yang dirancang oleh guru pertama yaitu unjuk kerja/praktik/kinerja pada salah satu materinya tidak sesuai dengan tujuan pembelajaran yang telah ditentukan, dikarenakan guru tersebut tidak menentukan tujuan pembelajaran yang akan dicapai pada aspek keterampilan. Selanjutnya instrumen penilaian sikap yang dirancang oleh guru pertama yaitu penilaian observasi terrhadap siswa telah dirancang dengan baik.

Terkait

pelaksanaan penilaian pembelajaran kedua guru menyatakan mereka menerapkan beberapa penilaian otentik seperti tes tertulis, 
penugasan, praktik/diskusi dan melakukan observasi terhadap siswa dikelas. Akan tetapi dalam pelaksanaannya kedua guru tidak menggunakan instrumen penilaian yang telah disusun sebelumnya dengan alasan banyaknya aspek yang perlu dinilai dan diperhatikan. Hal ini sejalan dengan hasil wawancara terkait kesulitan dalam melakukan penilaian menggunakan kurikulum 2013 kedua guru menjawab bahwa mereka mengalami kesulitan dalam melaksanakan penilaian sesuai tuntutan kurikulum. Karena banyaknya aspek yang perlu dinilai serta guru tidak mampu melakukan penilaian ini pada masing-masing individu siswa. Dalam panduan penilaian untuk Sekolah Menengah Atas terdapat 3 aspek penting dalam penilaian yaitu aspek sikap, keterampilan dan pengetahuan.

Selanjutnya ketiga aspek penilaian tersebut di jabarkan lagi kedalam beberapa bagian misalnya pada aspek sikap, guru harus mengisi lembar penilaian dengan menggunakan beberapa jenis teknik penilaian seperti observasi, penilaian diri dan penilaian teman sebaya, pada penilaian keterampilan juga menggunakan beberapa teknik, begitu pula dengan penilaian pengetahuan. Karena banyaknya aspek-aspek penilaian tersebut sehingga guru mengalami kesulitan dalam menerapkan penilaian pembelajaran di dalam kelas sesuai tuntutan kurikulum.

Oleh karena itu dapat dikatakan bahwa dalam melaksanakan penilaian

pembelajaran menggunakan kurikulum 2013, kedua guru masih mengalami kesulitan terutama dalam menggunakan format-format penilaian pembelajaran kurikulum 2013.

\section{KESIMPULAN}

Berdasarkan hasil penelitian dan pembahasan dapat disimpulkan bahwa :

1. Kesulitan yang dihadapi guru kimia di SMAN 03 Bombana dalam penyusunan rencana pelaksanaan pembelajaran dapat dilihat dari persentase RPP yang diperoleh yaitu $75,6 \%, 83,7 \%, \quad 70,2 \%$ dan $71,6 \%$ yang menandakan bahwa guru masih mengalami kesulitan dalam merancang RPP terutama terkait isi dari setiap komponen RPP sesuai tuntutan kurikulum 2013

2. Pelaksanaan pembelajaran dengan kurikulum 2013 di SMAN 03 Bombana mengalami kesulitan pada penerapan pendekatan saintifik dan juga model pembelajaran yang sudah ditetapkan sebelumnya. Karena kemampuan akademik siswa yang kurang baik dan siswa yang pasif dalam proses pembelajaran sehingga guru sulit untuk menerapkan pendekatan saintifik dan menggunakan model pembelajaran yang sudah ditetapkan dalam RPP sebelumnya. 
3. Penilaian hasil pembelajaran, dari hasil analisis instrumen penilaian kedua guru belum menyiapkan instrumen penilaian dengan baik. Hal tersebut dapat dilihat dari instrumen penilaian dalam RPP yang di rancang oleh guru. Guru pertama menyiapkan instrumen penilaian dengan cukup baik, meskipun terdapat beberapa jenis penilaian yang tidak digunakan. Hal ini dapat dilihat pada instrumen-intrumen dalam RPP yang dibuat guru. Sedangkan guru kedua tidak merancang penilaian pembelajaran. Serta pada pelaksanaa penilaian kedua guru tidak menggunakan instrumen penilaian dikarenakan banyaknya aspek yang harus dinilai sehingga guru kesulitan untuk menggunaan instrumeninstrumen tersebut.

\section{PUSTAKA}

Anwar R. 2014. Hal-Hal yang Mendasari Penerapan Kurikulum 2013. Humanira. 5(1), 97-106.

Budianto, M. A. K., Lud, S., dan Ali, M. 2016. Implementasi Pendekatan Saintifik dalam Pembelajaran di Pendidikan Dasar di Malang. Proceeding Biology Eduation Conference. 13(1), 46-51.

Diharja, P. 2017. Implementasi Kurikulum 2013 dalam Meningkatkan Mutu Pembelajaran PAI Siswa di
SMAN 5 Bandar Lampung. Skripsi.

Ekawati, Y. N. 2017. English Teacher's Problems in Applying the 2013

Curriculum. Journal of English Education. 6(1), 4148.

Fakhurrazi. 2018. Hakikat Pembelajaran yang Efektif. Jurnal At-Takfir. 11(1), 8599.

Harahap, R.D, dan Nazliah R. 2019. Analisis Perencanaan Pembelajaran (RPP) Biologi Kurikulum 2013 Kelas X Semester 1 Tahun Ajaran 2016/2017 di MAS Islamiyah Gunting Saga Kualuh Selatan Kabupaten Labuhanbatu Utara. Jurnal Biolokus. 2(2), 194-200.

Jafar, R. A., Sumiati, S., dan Maryono. 2018. Pengaruh Metode Everyone is $A$ Teacher Here terhadap Motivasi dan Hasil Belajar Siswa Kelas X SMA Negeri 18 Makassar pada Materi Pokok Ikatan Kimia. Jurnal Chemica. 19(1), 36-45.

Kusumastuti, A., Sudiyanto., dan Dini Octoria. 2016. Faktor Faktor Penghambat Guru dalam Melaksanakan Kurikulum 2013 pada Pembelajaran Akuntansi di SMK Negeri 3 Surakarta. 
Jurnal Tata Arta. 2(1). 118133.

Nadzir, M. 2013. Perencanaan Pembelajaran Berbasis Karakter. Jurnal Pendidikan Agama Islam. 2(2), 340-352.

Romadhoni, F. 2017. Pola Komunikasi di KalanganPecandu Game Let's Get Rich di Komunitas Xlite Tenggarong. Jurna IIImu Komunikasi. 5(1),235-247.

Sofyan, H. 2016. Pembelajaran Problem Based Learning dalam Implementasi Kurikulum 2013 di SMK. Jurnal Pendidikan Vokasi. 6(3), 260-271.
Sugiyono. $2017 . \quad$ Metode Penelitian Kualitatif. Yogyakarta: Alfabeta.

Suyatmini. 2017. Implementasi Kurikulum 2013 pada Pelaksanaan Pembelajaran Akuntansi di Sekolah Menengah Kejuruan. Jurnal Pendidikan IImu Sosial. 27(1). 60-68.

Trisnawati., Gunawan., dan Hasan, N. 2016. Perbandingan Implementasi Kurikulum Tingkat Satuan Pendidikan (KTSP) dan Kurikulum 2013 di SMAN 1 Sinjai Utara. Jurnal Miral Management. 1(1), 1-9. 